\title{
ŠEST OPĆIH OZNAČITELJA VELEBITSKE PRIMORSKE PADINE I PITANJE O REVITALIZACIJI
}

\author{
Ivan Rogić \\ Hvarska 11 \\ HR10000 Zagreb
}

\author{
UDK: 332(497.5 Velebit) \\ 711.435-168(497.5 Velebit) \\ Izvorni znanstveni članak \\ Ur.: 2016-10-22
}

Rad se dijeli na dva osnovna dijela. U prvom dijelu analizira se šest osnovnih označitelja s pomoću kojih se oblikuje postojeći značenjski okvir identifikacije Velebitske primorske padine u javnom znanju i imaginaciji suvremena hrvatskog društva. To su: nadmoć prirodnih sila; dubinsko siromaštvo; ekstremni ergonomijski (radni) tlak; tehnička konzervativnost mjesnog društva; slaba socijalna gustoća; rasutost razvojnog subjekta područja. Kada se ta obilježja promatraju međusobno svezano, dobiva se semiotični "portret" područja ne samo bez valjane razvojne budućnosti nego i područja za razvoj funkcionalno nesposobna. Stoga se u drugom dijelu rada aktualizira pitanje o uporištima revitalizacije područja. Koristi se pojam: revitalizacija, jer se njome teži naznačiti kako je mjesno društvo, odgovarajućim praksama revitalizacije potrebno tek pripremiti za aktivni/autonomni razvitak. Na tom se tragu analizira šest osnovnih uporišta (moguće) revitalizacije. To su: promjena javne predodžbe o subjektu mjesnog razvitka; nova kulturna strategija u odnosu na područje; definicija nove funkcionalne vrijednosti područja na nacionalnoj razini; (re)valorizacija prometne cjelovitosti područja; oblikovanje gospodarske strukture relativno neovisne o prirodnoj osnovi područja; izgradnja mreže razvojnih institucija. Svako spomenuto uporište počiva na svojevrsnim "snopovima" posebnih praksa koje ga sadržajno diferenciraju. No bitno je, pri tomu, podsjetiti kako se skiciranim revitalizacijskim pristupom sugerira međusobna povezanost socio/kulturnih promjena, promjena u gospodarskoj politici i politici. infrastrukture te u izgrađivanju specifične mreže razvojnih ustanova. Ili, drugačije rečeno, po srijedi je područje gdje se klasičnim "sektorskim" pristupom mjesnom razvitku ne će postići očekivani rezultati.

Ključne riječi: Velebitska primorska padina, revitalizacija

\section{Uvod ili o kocki koja ukida slučaj}

U ovom tekstu ne cilja se na izradu analize što bi imala završiti upućivanjem na cjelovitiju predodžbu o identitetu Velebitske primorske padine. Tomu je protivna već i činjenica da je padina područje, teritorij, nije društveni 
sudionik. U liku posebna društvena sudionika možemo ga, eventualno, predočiti odvažimo li se na književne postupke. No, očito je da se tako dobiveni uradak ne može prihvatiti kritički kao mjerodavna analiza identiteta: ne može prekoračiti crtu koja dijeli izmišljotinu, makar i "istinitu", od rezultata metodologijski propisane znanstvene analize. Cilja se, pak, na izradu jedne vrsti orijentirajuće skice nekih uočenih semiotičnih obilježja po kojima se u hrvatskom društvu, u javnom društvenom pamćenju i komuniciranju, razlikuje, diferencira, Velebitska primorska padina. Vidljivo je kako većina tih obilježja "mutira" i u posebne označitelje načina života na području. Stoga nije posve pogrešno držati ih dvosmislicama. Ne treba od njih bježati. Nerijetko su dvosmislice i točnije i sadržajno bogatije od brojnih izjava navodna jasnoća kojih sve duguje apstraktnim obvezama teorijskog ili komunikacijskog podrijetla.

Promatraju li se spomenuta semiotična obilježja povezano razložnom izgleda predpostavka kako nastalo značenjsko polje može utjecati na stavove i odnose društvenih sudionika spram Velebitske primorske padine i tamnošnjeg podgorskog društva. Može, dakle, djelovati kao neka vrst "nadodređujućeg" čimbenika tragovi kojega se ugrađuju u množinu posebnih praksa. Za ovu skicu izgleda najkorisnije ukazati kako spomenuto značenjsko polje utječe na oblikovanje simbolična obzora u okviru kojega se određuju središnji ciljevi razvitka područja i definiraju polazna pitanja o revitalizaciji mjesnog društva.

$\mathrm{Na}$ ovom mjestu nameće se prigodna usporedba načina djelovanja spomenuta značenjskog polja $\mathrm{s}$ - bacanjem kocke. U tekstu se opisuje šest osnovnih semiotičnih obilježja što se adresiraju na podvelebitsko primorsko područje. Svih šest negativno označuju područje. Zamislimo li da je svako obilježje napisano na po jednoj strani kocke (kocka ima šest strana) bacanjem kocke mijenjat će se pojedina obilježja, ali će zaključni rezultat bacanja ostati nepromijenjen: negativna označenost područja. To je posve suprotno, primjerice, onomu što je Stephane Mallarmé, francuski pjesnik i utemeljitelj moderne poetike, svojedobno (1897.) sugerirao naslovom poznate prozne poeme: Jedno bacanje kocaka ne ukida slučaj. Ako kocka ima šest strana, i ako je na svakoj upisano obilježje s drugim značenjem, vjerojatnoća što se bacanjem stavlja u pogon uvijek ostavlja otvorena vrata hirovitosti (čitaj: kreativnosti) slučaja. No, ako je u igri šest posebnih obilježja ukotvljenih u istom negativnom značenjskom polju, igra slučaja (mijena upisanih obilježja) ograničuje se na događajnu površinu. Ispod ili iza nje djeluje spomenuti "nadodređujući" čimbenik. On nije upisan u svaku mijenu na površini, ali njegova "gravitacijska" snaga ne dopušta događajnom polju otrgnuti se od njegovih "gravitona". 
Ne izgleda korisnim upustiti se dalje u eventualna gombanja s (post) strukturalističnim implikacijama ponuđene usporedbe. Dostatno je podsjetiti kako se nagoviještena, a manje vidljiva, značenjska stega, jezičnom i kulturnom ustrajnošću, ali i navlastitim društvenim upravljanjem poželjnim/nepoželjnim osjećajima, ugrađuje i u društveno djelovanje kojim se ima odgovoriti na pitanja o razvitku i budućnosti pojedinih područja i mjesnih društava tamo prisutnih. Prihvatimo li tvrdnju kako su interesi racionalno definirani orijentiri djelovanja društvenih sudionika zaključiti je kako spomenuti značenjski utjecaji mogu, ali ne moraju, imati isti vektor kao i interesi. Na ovom su mjestu kritička pitanja o obzoru razumijevanja mogućnosti razvitka i revitalizacije mjesnog društva - nezaobilazna.

\section{Nadmoć prirodnih sila}

U sada već klasičnu radu: Velebitska primorska padina, objavljenu 1958., autor, Veljko Rogić, podsjeća na nekoliko osnovnih činjenica. Prva se očituje u nadmoći planine, u ovom slučaju Velebita, na području. Planina, točnije: Velebitski planinski lanac, glavnim je prirodnim čimbenikom područja. Druga činjenica očituje se u primorskom obilježju područja. Nazire se shema po kojoj se na području suočavaju dva jednako neukrotiva prirodna elementa: planina i more. Napose, uzme li se u obzir vjetar, točnije, bura, zahvaljujući kojoj se more u Velebitskom kanalu preobražava u teško savladivu prirodnu silu. Nije posve netočno, na tom tragu burnom moru pridružiti prispodobu: planina u pokretu. U takvoj se zbilji primorske prednosti područja poništavaju nadmoćnošću planine; planinske prednosti morskom neukrotivošću. Rijetko se sastaju u, za čovjeka dobitnoj, kombinaciji.

Iduća činjenica u ovoj igri nadmoćnih prirodnih sila je vrst reljefa i kakvoća tla. Uvide ponuđene u množini posebnih analiza dopušteno je svesti na oznake kao što su: brdovito i strmo područje; kamenjar; manjak obradiva tla; sušna klima; zaraslost u šikaru. Nisu bez temelja u mjesnim žargonima važne riječi kao što su: oštrulj, škrapa, greda, kada treba odrediti granično iskustvo mjesnog društva stečeno u suočavanju s kakvoćom tla. Premda i nije posve mjesno specifična, nije nekorisno podsjetiti i na uporabu riječi: točilo. Na prvi pogled, riječ bi imala značiti svaki izvor - tekućice. No na području ta se riječ rabi, ponajprije, za označiti kamenu kosinu s množinom usitnjena kamenja što se nizbrdo "toči". Rastresena podloga i množina sitna kamenja ne dopuštaju ni najodpornijem bilju ovdje se ukorijeniti. Po srijedi je neka vrst pustinje što se "toči". 
Daljnja označiteljska stilizacija dopušta skicirane sheme dovesti do prigodna sažetka omeđena riječju: ištipanost, hrapavost. Riječi: ištipanost, poznato je, književni je autoritet zajamčio Janko Polić Kamov (naslovom: Ištipana hartija). Premda Polić Kamov mjestom rođenja ne pripada na Velebitsku primorsku padinu (rođen je na Sušaku), nije ga ta činjenica uspjela cijepiti eventualnom nebrigom zacijelo i stoga što u razdoblju njegove mladosti (starost nije ni dočekao), na prijelazu iz devetnaestog u dvadeseto stoljeće, "ištipanost" određuje široku značenjsku plahtu kojom se obvija pretežiti dio hrvatskog jadranskog sjevera. "Ištipanost" Velebitske primorske padine, njezina hrapavost, u takvoj je shemi mjestom radikalna zaoštravanja.

Naznačena značenjska shematizacija ne upisuje se samo u tkivo prirodne zbilje. Kako je u Uvodu nabačeno, ona teži "mutirati" i u značenjsko polje kojim se obvija mjesno, podgorsko, društvo. Zadaća "mutacije" je podrediti kakvoću društva kakvoći prirodne zbiljnosti, prometnuti je u njezin specifični "tematski" nastavak. S nešto više analitičke slobode na ovom je mjestu prikladno ponovo se obratiti na arhiv pjesništva. Netom preminuli (2015.) suvremeni hrvatski pjesnik, Nikica Petrak, svoje zaglavno autorsko iskustvo sabire pod složenicu: ispadanje iz povijesti. Spomenute "mutacije" glavnih označitelja prirodne zbiljnosti Velebitske primorske padine u označitelje mjesnog društva, u osnovi, osnažuju, dakle, u javnoj imaginaciji sliku mjesnog društva koje, u bitnom, i ne pripada povijesti nego nekoj vrsti pred/povijesti, njome vladaju prirodne, nikako društvenom voljom usmjerivane sile. Ono je - ispalo iz povijesti. Treba li podsjetiti kako je "ispadanje iz povijesti" neodvojivo od ispadanja iz kulture. "Ištipana", hrapava, prirodnost područja imala bi je posve zamijeniti.

Podsjetiti je, međutim, kako se teritorijalni doseg te značenjske mutacije ne poklapa posve s teritorijalnim opsegom cijelog područja: izmiče joj grad Senj (Teritorijalni obris grada Senja ne treba brkati s današnjim područjem jedinice lokalne samouprave naslovljene: Grad Senj; ono obuhvaća nemali dio Velebitske primorske padine na koje se "ispadanje iz povijesti" i adresira.) "Opiranje" grada Senja skiciranoj redukciji izvire izravno iz njegove gradskosti. Već po definiciji, grad je društvenim sudionikom što se oblikuje aktivnim odporom (zlo)voljama prirode i težnjom $\mathrm{k}$ njihovoj racionalnoj uporabi. K tomu, povijesna baština Senja spada u skupinu najbogatijih gradskih baština u Hrvatskoj. Dosegu izmiču i još neka naselja na Velebitskoj primorskoj padini, navlastito Karlobag, Jablanac, Obrovac. Premda je njihova "gradolikost" negdje na pol puta između grada i sela, njihove obveze u poslovima specifičnim za središnja naselja (uprava, naobrazba, zdravstvo, način građenja) dodatno osnažuju odpor opisanim značenjskim redukcijama. Vidljivo je, dakle, da se 
teritorijalni doseg područja koje se obvija značenjskim plaštom "ispadanja iz povijesti" (u "hrapavu" prirodnost) okvirno poklapa s područjem i mrežom seoskih naselja na Velebitskoj primorskoj padini. U razdoblju pedesetih godina prošlog stoljeća, kada Veljko Rogić radi na spomenutoj analizi, još se tamo može uočiti, približno, tristotinjak sela i zaseoka.

Simbolično, a onda i funkcionalno, isključivanje iz povijesti na području olakšavaju dvije činjenice u kojima, priznati je, kakvoća prirode ima nezanemarivi udio. Obje su, $\mathrm{k}$ tomu, upisane u prastare tradicije pa im se, toliko lakše, dopisuje i "izvorna" prirodnost. Na prvu takvu činjenicu podsjeća Marko Valentić (2013.). Pokazuje se kako je planina, planinski kompleks, u feudalnom institucijskom okviru a, očito je, i u onima što mu predhode res nulius, ničijom zemljom. Taj položaj planina, planinski masiv, nema u institucijskom okviru moderne nacionalne države, a ne može ga ni imati. Ali se tradicijskom ustrajnošću u sjećanju tamnošnjih zajednica oblikuje uvjerenje kako "planincima", (u mjesnom žargonu "gornjašima"), "prirodno" pripadaju "slobode" koje nisu posve sukladne općem institucijskom poretku moderne nacionalne države, napose njezinim težnjama $\mathrm{k}$ političkoj centralizaciji $\mathrm{i}$ građanskoj standardizaciji. Prakticiranje takvih sloboda (mjesna odvojenost, specifične običajne i moralne norme, srodničko povjerenje, samoorganizacija "odozdo", i srodne) lako podliježe "subverzivnu" označivanju. Sukladno tomu, na takve se zajednice lako prijenose i prije spomenuti, "mutirani" označitelji, izvedeni iz označivanja teritorija i prirodne zbilje. Pa one postaju "hrapave", "divlje", "nepouzdane", i, općenito, manje sposobne za civilizirani život. "Prirodno" im je mjesto na rubu povijesti ili izvan nje.

Kao što je poznato, u nekim radovima Dinka Tomašića, jednog od pionira hrvatske sociologije, ističe se važnost razlikovanja socijalnih i kulturnih tradicija gorštačkih i nizinskih, dinarskih i panonskih, zajednica. Uočavanje tih razlika toliko je važnije koliko je i njihovo urastanje u prakse modernog društva različito. Tomašić ističe kako nije dopušteno nekritično idealizirati "obilježja "dinarskih", gorštačkih, zajednica na štetu drugih, navlastito zajednica nastalih na nizinskim područjima. U tomu on vidi "balkanske" političke intencije, ugrađene u srpske osvajačke programe. One (zlo)rabe i posebni smjer romantične imaginacije koji planini, dubravi, dopisuje osloboditeljsku zalihu. (Njezinim autorskim predcima u hrvatskoj književnosti, primjerice, mogu se držati Petar Zoranić i Ivan Gundulić.) No u Tomašića nije razvijeno pitanje o zapletima u semiotičnu kratkom spoju kojim se planinsko stanovništvo premješta u pred/povijest i prirodnu "hrapavost", "divljačnost". 
Tek je zaključiti kako se takva značenjska redukcija u "pitomijim", nizinskim, područjima, može puno teže ustaliti.

Na drugu činjenicu upućuju brojne analize i bilance obradiva zemljišta. Sve upućuju na manjak valjana zemljišta za poljodjelstvo. Ista se ocjena ponavlja i u najnovijim izvješćima o stanju u prostoru za razdoblje 2010. - 2014., za područja jedinica lokalne samouprave: Grada Senja, i općine Karlobag, objavljenim 2015., godine. Raspoložive ratarske površine u ukupnoj bilanci imaju tek simbolični udio. Praktično promatrano, to znači da je po srijedi veličina pogodna, pretežno, za okućno poljodjelstvo, ili za uzgoj posebnih, ekologijski specifičnih, kultura, (koji uzgoj nije opterećen zahtjevima za kolikoćom). Upućuje se, također, na nemale pogodnosti za razvoj stočarstva (pretežno ovce, koze). Ono je, poznato je, u višestoljetnom razdoblju, sve do kraja "starog Podgorja", (kako voli reći Stjepan Vukušić, 1988.), osnovnom granom poljoprivrednog gospodarstva na Velebitskoj prirodnoj padini. Obje spomenute grane prirodno osnažuju sezonske selidbe stanovništva po popriječnici obala/planina te navlastitu nomadsku tradiciju. Obično se snažniji poticaj tomu vidi u stočarstvu. Na višim razinama, "podima", Velebitske primorske padine, (približno iznad 600-700 metara), nalaze se i veći i bolji pašnjaci. Pa je puštanje stoke, "blaga", u toplijem razdoblju godine na te pašnjake i više nego korisno. No rjeđe se ističe kako isto nomadsko kretanje ima korijen i u skromnim bilancama poljodjelskog zemljišta bliže obali. Sezonsko nomadsko kretanje mjesnog stanovništva ovdje se svodi na pokušaje "okrupnjavanja" raspoloživa zemljišta. Parcele, dakako, ostaju fizički raspršene; ali ih nomadska/sezonska obrada funkcionalno spaja u veće gospodarske jedinice. $\mathrm{K}$ tomu, tako se osigurava i bolji pristup potrebnoj ogrjevnoj građi.

$\mathrm{Za}$ europska društva, utemeljena na čvrstu posjedničkom nadzoru obradiva zemljišta, nomadske su skupine, poznato je, dugoročnim izvorom zebnje i nelagode. Njihovo teritorijalno ponašanje $\mathrm{s}$ korijenom u oprečnu predlošku raspolaganja zemljištem nerijetko je povodom oštrih sukoba, kadšto i oružanih. Premda se nomadi/stočari različitim ugovorima s nositeljima zemljišnih ovlasti nastoje staviti pod nadzor i "socijalizirati", dubinsko nepovjerenje zemljišnih poredaka spram "tekuće" prirode njihova ponašanja na teritoriju ostaje trajno prisutno. Koliko je vidljivo, to nepovjerenje ne kopni ni u modernom razdoblju, (približno od sredine 19. stoljeća dalje). Premda je moderna mobilizacija zapadnih društava veći dio seljačkog stanovništva pokrenula, i prometnula u (nove) industrijske nomade, stara razdiobna pukotina između pokretnih ("stočara") i sjediteljskih ("ratara") nije se na simboličnoj razini posve obrisala. Razlika: domaći - doseljeni upisuje se i danas u množinu teritorijalnih zajednica. 
$\mathrm{Na}$ Velebitskoj primorskoj padini ne uspostavlja se pukotina između stočara i ratara; razlog je jednostavan: cijela seljačka populacija je u tom dvojstvu/ jedinstvu. Pukotina se, naprotiv, pomiče na izvanjsku granicu; ona dijeli seljački svijet Velebitske primorske padine od tankog sloja gradskog stanovništva u Senju (i u ostalim obalnim naseljima prijelazne vrsti); te razdvaja područje od susjednih područja: otoka; zadarskog područja na jugoistoku i primorskog kraja na sjeverozapadu. Otisci prirodne hrapavosti, sirovosti, života određena nadmoći planine, i sezonskog nomadskog kretanja po popriječnici obala - planina, u imaginaciji stanovništva na spomenutim susjednim krajevima djeluju kao jedna vrst moćne potpore značenjskom potiskivanju i pučanstva i same Velebitske primorske padine - iz povijesti. Malo na to utječu, primjerice, nezanemarivi uspjesi mjesnog društva u pomorstvu i ribarstvu, napose od sredine 19. stoljeća, (osim u Senju, Svetom Jurju ili Karlobagu, vidljivi su i u manjim naseljima, primjerice, u Lukovu, Donjoj Kladi, Barić Dragi). Ustaljuje se značenjski omot dugoročno odporan na različite protimbene čimbenike. Pa "ispadanje iz povijesti" ostaje na djelu i u razdoblju očita sutona "starog Podgorja", od osamdesetih godina prošlog stoljeća dalje. U glavnoj su ulozi prirodne sile i društveni sudionici više "prirodni" negoli društveni.

Skiciranim se semiotičnim mutacijama posebno obvijaju dvije zajednice na Velebitskoj primorskoj padini. Prva su, poznato je, Morlaci, Crnovlasi, "Crnogunjci". U mletačkim papirima morlačko se ime rabi trovrstno: označuje konkretnu društvenu skupinu, starohrvatske Vlahe; velebitski planinski lanac (montagna della Morlacca); morski prolaz između podvelebitske obale i otoka (canale della Morlacca, canalis Morlachorum). Od pomorske i trgovačke despocije, kakva je mletačka bila, načelno bi trebalo očekivati više razumijevanja za učinke morlačke nomadske pokretljivosti. No uspostava mletačke teritorijalne vlasti na jednom dijelu Velebitske primorske padine (jugoistočno od Karlobaga) pokazuje drugo. I ona, kao i druge teritorijalne vlasti, teži morlačke nomade podvrgnuti trajnom nadzoru. Stoga ih mora označiti "divljačnima", nepouzdanima, nedoraslima zahtjevima kulture. Na drugoj strani, budući da je zainteresirana za stalnu nastanjenost na području, dakle, i za opstanak morlačke zajednice, ne može je izložiti nasilnom iskorijenjivanju. Ustaljuje se dvovrstna praksa kojom se, u isti mah, morlačka zajednica označuje "prirodnom", ispalom iz povijesti i kulture, i podvrgava ne samo volji vlasti, nego i kulturnoj preradi, "civiliziranju". Domašaj te prerade ne probija granice odnosa kojim se MorIaci na području definiraju instrumentalno: oni su sredstvom, najprije nastanjivanja teritorija, a poslije (u ratovima s osmanskim carstvom) i njegove obrane. Sredstvo ne može biti društvenim sudionikom. Zato se trajno obvija označiteljima koji 
ga u značenjskom polju raspoređuju negdje između prirodne sile i društvene životinje. Na tragu analize Nina Raspudića (2010.) nije netočno takvu praksu označiti poluorijentalizmom.

Uočiti je, međutim, kako se mletačka uporaba skicirana modela djelovanja ne iscrpljuje u odnosu spram starohrvatskih Vlaha. U razdoblju prije doselidbe Bunjevaca, u 17. stoljeću, na području živi i starohrvatsko stanovništvo od njih različito, napose u primorskim naseljima kao što su Sveti Juraj, Starigrad, Jablanac, Stinica, Karlobag. Mletačka generalizacija tu činjenicu ne drži važnom. Uporaba morlačkih imena i izvedenica adresirana je na cjelinu područja. Posredno, to znači da su i druge, ne/vlaške, starohrvatske zajednice na području, iz mletačke perspektive - istovrsne starohrvatskim Vlasima, zajednicama koje samo što nisu ispale iz povijesti i kulture. Da je ova sugestija više od hipoteze može se argumentirati i načinom označivanja što ga mletačke vlasti koriste u sukobu s uskocima. Uskoci nisu Morlaci. Pa ipak, osim što se "portretiraju" razbojničkim atributima, na njih se baca i sumnja na - kanibalizam. Praktična svrha te potvore posve je jasna. Ali se mora uzeti u obzir da se ona oblikuje redukcijom jednog društvenog sudionika na status - prirodne sile i prirodne pošasti. Uskoci su na Velebitskoj primorskoj padini, poznato je, "u prolazu". Pa se već i odlaskom s područja, početkom sedamnaestog stoljeća, odvajaju od spomenutih, negativnih, označitelja. Ali se isti označitelji od samog područja - ne odvajaju.

Druga su skupina Bunjevci. Bunjevačke skupine nastanjuju područje, kako je spomenuto, tijekom sedamnaestog stoljeća, nakon približno stogodišnje odsutnosti ikakva stanovništva na području (1525. - 1630.). Pavle Rogić (1966.) podsjeća da je pored Bunjevaca na područje doseljeno i nebunjevačko stanovništvo, (napose u obalna naselja s funkcijama mjesnih središta, no njegov je statistički udio u mjesnom društvu manjinski). Od čakavskih zajednica u susjedstvu, Bunjevce jezično odvaja "lička" ikavica. Od područja civilne Hrvatske odvaja ih upravljački i organizacijski okvir Vojne granice te položaj slobodna seljaka/vojnika. U njihovo ponašanje upisuju se viševrstni tragovi života nastali ili ojačani u hrvanju s Velebitskom primorskom padinom: nomadska stočarska "prtljaga"; popriječno kretanje more/planina; privrženost samoorganizaciji "odozdo"; seljačka udaljenost od senjskog urbaniteta. U osnovi, vojne obveze i katolička vjera glavne su poveznice sa svijetom izvan područja. Približno, od sredine devetnaestog stoljeća i slabljenja vojnograničnih upravljačkih okvira, ponajviše zahvaljujući potrazi za poslom u pomorstvu, ribarstvu, građevinarstvu, prijevozu, poveznice se množe i trasiraju put utjecajima do tada nepoznatima. Na okretu stoljeća, i prijelazu u dvadeseto, 
povećava se važnost odselidbe: u američko inozemstvo, u plodnije hrvatske krajeve (Šlavonija), u susjedne gradove na sjevernom hrvatskom primorju (Senj, Novi Vinodolski, Sušak, Istra), najposlije u Zagreb. Tada se ustaljuje i nova poveznica: zajednice u dijaspori.

Tijekom većeg dijela razdoblja većinske prisutnosti Bunjevaca na Velebitskoj primorskoj padini, (okvirno 17. - 20. stoljeće) održavanje stalne nastanjenosti i vojna obrana područja glavne su "javne" obveze bunjevačkog stanovništva. Baš kao i odnos mletačkih vlasti spram hrvatskih starovlaških zajednica i odnos vojnograničnih vlasti spram bunjevačkog pučanstva prožimlje, prije spomenuti, instrumentalni interes. Presudna je njihova "funkcionalnost" u cjelini poretka. Mjerila te funkcionalnosti poklapaju se s, prije spomenutim učincima života određena hrvanjem s Velebitskom primorskom padinom. Na toj se podlozi, bez većih teškoća, kontinuirano množe i obnavljaju označitelji koji i Bunjevce omataju značenjskim omotom skupine ne posve izvan povijesti, ali na njezinu rubu. Oni su toliko priznati unutar povijesti (i, dakako, kulture) koliko je nužno za održavanje stalne nastanjenosti i vojne obrane područja. Oni su toliko isključeni iz povijesti koliko je potrebno za njihovu redukciju na funkcionalno sredstvo poretka. Zato ih se bez teškoća locira "prirodnim" označiteljima kako je naznačeno, između prirodne sile i društvene životinje. A $\mathrm{k}$ tomu lijepe im se i oznake predhodno već upisane u podvelebitski teritorij: primjerice, Vlasi, rjeđe MorIaci ili uskoci. Množina tih naslova vodi ih bliže prirodnoj divljini nego li društvenoj zbilji. Zato im se poslije, kada ih odselidbe suočavaju s ostalim zajednicama u susjedstvu, teško priznaje da su - Primorci. Naprotiv, oni su - Podgorci.

Tijekom dvadesetog stoljeća obje "klasične" funkcije Bunjevaca u okviru poretka: održavanje stalne nastanjenosti i vojna obrana područja, nestaju. Pače, u drugojugoslavenskom razdoblju održavanje stalne nastanjenosti područja promeće se u neku vrst retrogradna teritorijalnog ponašanja budući da poredak svoja glavna uporišta nalazi u gradskim i industrijskim središtima, a napuštene teritorije ostavlja "spontanom razvitku". U istom razdoblju snaženje novih mjerila kakvoće osobnog i obiteljskog života radikalno slabi prihvatljivost uvjeta života kakvi su se ustalili u višestoljetnom predhodećem razdoblju opstanka na rubu, u/izvan, povijesti. Masovna odselidba, napose u razdoblju 1965. - 1990., u osnovi, razuman je odgovor na nastale (ne)prilike. No s tom odselidbom odseljeni teže još jednom dobitku, s onu stranu profesionalnih ili gospodarskih uspjeha. Teže prekoračiti granice semiotična omota kojim je bila do tada omotana javna predodžba o bunjevačkoj zajednici na Velebitskoj primorskoj padini. Jezikom Giorgia Agambena (2002), teže drugačijoj 
priznatosti, koja ništa ne duguje semiotičnu "zarobljivanju" prirodnim označiteljima i potisnutosti na rub, u/izvan, povijesti. Na drugoj strani, prisutnost takvih označitelja u samooblikovanju bunjevačkih predodžaba o vlastitoj zajednici ne može se ni zanijekati. Koliko se vidi, na redu je kritička valorizacija te simbolične "prtljage".

\section{Dubinsko siromaštvo}

Označitelji siromaštva nisu, izvana promatrani, baš bliski označiteljima koji upućuju na nadmoć prirodnih sila na području. "Izvorno" su smješteni na socijalnom i gospodarskom polju. Pa je vjerovati kako osnažuju odvojenost područja od nadmoći prirodnih sila. No uzmu li se u račun raznoliki, negativni, učinci siromaštva na ljudski život lako je uočiti kako ih "pozadinski" veže zajednički označitelj: svodnja ljudskog života na ne/ljudski, zaoštrenije: životinjski. Siromaštvo, dakle, (također) radi na "ispadanju iz povijesti" siromašnih.

Izravnija veza siromaštva s obilježjima područja na Velebitskoj prirodnoj padini nagoviještena je već prije: isticanjem manjka obradiva zemljišta, raširenošću kamenjara, nepovoljnom klimom, brdskim reljefom. Posredno se i time pokazuje kako se siromaštvo na području Velebitske primorske padine ne može posve oteti od veze s "prirodnošću" područja. Drugačije rečeno, i ovdje je moguće uočiti svojevrstno "mutiranje" prirodnih označitelja područja. Jedan smjer mutacije, dakle, vodi od prirodnih prema društvenim označiteljima siromaštva. Drugi vodi obratno: od društvenih prema prirodnim označiteljima (simboličnu izgonu iz povijesti).

Po ocjeni Stjepana Vukušića (1988.), ključnu cjelovitu javnu predodžbu o siromaštvu na podgorskom području oblikovali su književni radovi Vjenceslava Novaka. Tri su njegova djela u tom pogledu pionirska: Fiškalova ispovijed (1886.); roman: Pavao Šegota (1888.); Podgorske pripovijetke (1889.). Podgorcima je, na toj, novakovskoj, podlozi trajno dopisan naslov: velika sirotinja. Uočiti je: naslov se dodjeljuje u razdoblju razvojačenja područja Vojne granice, kada područje gubi strategijsku funkciju, a podgorsko pučanstvo mora u okviru nove "gramatike" hrvatske polu/modernosti pronaći i nove rješidbe starih teškoća. No Vukušić, držimo opravdano, primjećuje kako je Novakova "inventura" podgorskog siromaštva svojevrstnim "crnjakom" budući da izvan pozornosti ostavlja nemalu baštinu podgorskog odpora siromaštvu. Njezin je domašaj toliki da je moguće govoriti o nekoj vrsti heroičke ustrajnosti Podgoraca u tom odporu. Na tragu Manuela Castellsa, nije posve neprimjereno 
ovdje rabiti složenicu: identitet odpora. Podgorje dakle, podliježe siromaštvu. Ali je i u trajnom ratu protiv njega.

Za poznatiju ekonomsku "doradu" javne predodžbe o siromaštvu u Podgorju zaslužan je, zacijelo prvi, "terenski" rad u hrvatskoj sociologiji, izvješće o uvjetima života hrvatskog seljaštva naslovljeno: Kako živi narod, Rudolfa Bićanića. Idući tragom programskih težnja Hrvatske seljačke stranke, a služeći se istraživanjem "na terenu", Bićanić uspijeva ponuditi uvjerljivu i cjelovitu sliku uvjeta života na hrvatskom selu u kasnim tridesetim godinama prošlog stoljeća, (kada se okončava i prvo razdoblje hrvatske polu/modernizacije). Izvješće pokazuje kako su siromaštvo i novakovska "nezasitnost i bijeda" prisutne na cijelom hrvatskom seljačkom prostoru. Prilike na Velebitskoj primorskoj padini su "samo" nešto grublje i teže. U analizi, kroz pojam: agrarna prenapučenost, izbija i veza između brojnosti stanovništva na nekom području i ograničene plodnosti obradiva tla. Po podatcima iz godine 1924., na koje u jednom radu podsjeća Višeslav Aralica (2000.) na primorskom kršu obradivo je tek $6 \%$ ukupne površine. Prinosi s tih $6 \%$ dostaju za podmirivanje, približno, petine prehrambenih godišnjih potreba (jednoga) prosječna odrasla čovjeka; ili, dostaju za život tijekom dva mjeseca u godini. U već spominjanim izvješćima o stanju u prostoru (2010. - 2014.) na teritoriju Grada Senja (jedinica lokalne samouprave) i općine Karlobag, napisanim približno stotinjak godina potom, ističe se na sličnu tragu, kako u Podgorju valjana obradiva tla zapravo i nema (općina Karlobag) ili kako je njegov statistički udio ruban (1,6\% od ukupne površine Grada Senja). Jesu li spomenuti podatci u decimalu točni ili nisu ovdje nije odlučujuće. Važnijim izgleda zaključak koji se, osloncem na njih, nameće. On se (okvirno) može ovako formulirati: odvajanje seljačkog svijeta od siromaštva nije moguće koliko je taj svijet monofunkcionalno ovisan o obradi zemlje. Na njega u više radova podsjeća i Maja Štambuk, klasična autorica u hrvatskoj sociologiji sela. Drugačije rečeno, racionalna reakcija na prilike osnažuje težnje $\mathrm{k}$ formiranju - mješovita kućanstva. U strukturi njegovih prihoda prihodi od poljodjelstva kombiniraju se s prihodima iz drugih izvora. Koliko je vidljivo, premda s ograničenim uspjehom, i na podgorskom području rabi se taj model hrvanja sa siromaštvom. U naseljima na obalnoj crti usporedne su djelatnosti ribarstvo, pomorstvo, obrti; u "kontinentalnim" naseljima stočarstvo, šumarstvo, cestogradnja, prigodni obrti. Pak, napuštanjem područja radikalno se mijenja cjelina života, pa onda i način strukturiranja spomenute "mješovitosti".

Socijalistička modernizacija u razdoblju nakon 1945., nije uspjela uspješno "obračunati" s mjesnim siromaštvom. Pače, zabrana držanja koza 
(1954.) mjestimično je prilike i pogoršala. Na njih upućuju i raspoloživi statistički podatci, a i povremeni apeli mjesnih župnika (primjerice, Drage Babića, župnika u Svetom Jurju, Lukovu, Starigradu, Jablancu, pedesetih godina). Sve do sramežljiva oblikovanja mjesnog turističkog tržišta osamdesetih godina prošlog stoljeća ne naziru se gospodarske prakse s kojima se može računati na samom području kao s valjanim komplementarnim granama. Pa i nije netočno ustvrditi kako odselidba, napuštanje područja, napose od sredine šezdesetih, dugoročno nadsvođuje potragu za uspješnom mješovitošću. Na taj se način odvajaju od siromaštva - odseljeni Podgorci. Ali ne i Podgorje. Siromaštvo i dalje ostaje njegovim moćnim označiteljem. No sada se slika siromaštva postupno premješta prema - javnom prostoru. Zapuštenost krajolika, propadanje napuštenih kuća, nedostatna tehnička infrastruktura, substandardnost u opskrbi električnom energijom i vodom, otežana prometna pristupačnost, i srodne činjenice u toj slici zadobivaju sve oštrije obrise.

Sa siromaštvom se mjesnom društvu u Podgorju pridružuje i još jedan, negativni, označitelj: prosjačenje, i svojevrstna stigmatizacija složenicom: podaj majko. U lijepoj analizi Bojan Mucko (2009.) pokazuje kako je na djelu svojevrstno umijeće prijevare naslonjeno na umijeće "upravljanja dojmovima" o kojima govori Erving Goffman, jedan od začetnika interakcionističke analize. U tekstovima Vjenceslava Novaka prosjačenje je neodvojivo od podgorske stvarnosti. No uzmu li se u obzir njegovi kolikotni obrisi izgleda točnijom sugestija Stjepana Vukušića kako je njegovo isticanje učinak novakovske redukcije, pisanja "crnim po crnom". Podgorsku ekonomiju ne određuju ni "sive" ni "crne" ekonomske tradicije. Po tomu se ono ne razlikuje od drugih hrvatskih "zapuštenih" područja. Značenjsko "klizanje" složenice: podaj majko, prema položaju istaknuta označitelja područja olakšano je cjelinom značenjskog plašta koji područje obavija. Ono je "divlje", "neukroćeno", "nepouzdano", "egzotično"; pa bi trebalo biti i u gospodarskom pogledu - "crno".

Pogrešno je, a događalo se, s prosjačenjem svezati i rijetke, premda razglašene, primjere mjesnih ridikula. I oni žive od milostinje, ali ne prosjače. Prije će biti da su otiscima starih sredozemnih misterijskih likova pod izravnom zaštitom božje milosti i ljudske sućuti. Među posljednjima te vrsti upamćen je Luka Galota, i više nego "slavan" na potezu Senj - Jablanac - Karlobag, pedesetih godina prošlog stoljeća. Dobroćudan i lagano poremećen, tamnošnjem je pučanstvu i putnicima "vaporom" na redovitoj pruzi Rijeka - Pag, priređivao dojmljive predstave i koncerte. I, za pravo, uživao povlastice rijetko slobodne osobe. Možda je kroz takve likove, na rubu groteske, Podgorje sanjalo svoje snove o slobodnu životu kada već drugačije nije moglo. 


\section{Ekstremni ergonomijski (radni) tlak}

Složenica ponuđena u ovomu podnaslovu nije baš, na prvu loptu razumljiva. Stoga je, uvodno, korisno ovdje podsjetiti na jednu duhovitu dosjetku (engleskog) Irca, Oscara Wildea. U nekoj prigodi on je, navodno, uskliknuo: Bože, sačuvaj me tjelesnih muka, duševne ostavi meni. Spomenuti, ekstremni ergonomijski tlak, dakle, imao bi označiti nužnu veličinu tjelesnog napora koji se ima uložiti u brojne dnevne poslove. U pučkom žargonu, prisutnu i na podgorskom području, no ne samo na njemu, to se naprezanje, najčešće, opisuje dnevnom mukom i težačkim životom. Da nije po srijedi tek iznuda sućuti i odgovarajućih olakšica na korist takvih skupina dostatno je podsjetiti na neke primjere iz svakodnevice "starog" Podgorja. Recimo, fizička pristupačnost osnovnih škola djeci. Na nju, posredno, upućuje i Mirko Raguž u svojim osvrtima na "povijest školstva senjskoga kraja" (1990.). Mreža osnovnih škola po podgorskom kraju sukladna je, uglavnom, mreži obalnih naselja s osnovnim središnjim funkcijama. Djeca u tim naseljima tako su na dobitku. Ali djecu u okolnim naseljima, udaljenima i po sat, sat i pol, hoda do obalnih naselja gdje su škole, školska obveza, u isti mah, primorava i na naporno, barem jednosatno pješačenje, do škole/od škole, dakle, na svojevrstni, posebni, napor, koji ne dopušta "lagodno" odvojiti pohađanje škole od - naporna rada. Drugi primjer: pristupačnost vodenih izvora. Premda je gradnja kućnih "šterna" na području dijelom običajnog pristupa gradnji kuća, nemali je broj kućanstava "starog" Podgorja ovisio ili o komunalnim šternama ili o prirodnim izvorima vode, ne uvijek na "udobnoj" udaljenosti od naselja. U obiteljima s više članova voda se lako troši i u nemalim količinama. Stoga po nju treba ići i nekoliko puta dnevno. Pa je čak i donosidba malih količina svojevrstni - radni poduhvat.

Ponuđene, nasumično odabrane primjere, korisno je "poduprijeti" makar i grubim popisom skupina poslova gdje je prisutnost ekstremna radnog tlaka (iliti: težine posla) neuklonjiva. Zacijelo je jedan od važnijih poslova u toj skupini "proizvodnja" obradive zemlje: krčenje, gradnja suhozida, svladavanje kamenjara. Premda se, vidjelo se, manjak obradive zemlje nadoknađuje "popriječnim"/nomadskim kretanjem more/planina, stvaranje nove obradive zemlje u blizini stalnih prebivališta stalnim je imperativom. S takvim je poslovima tijesno svezana i skupina poslova na održavanju mjesnih putova, gdje su kamenjar i nagib terena na popisu najčešćih i najtežih zapreka. Dobra mreža mjesnih putova posebno je važna u razvitku teritorijalne sheme: more/ planina. Iscrpnija istraživanja (primjerice, Helene Knifić Schaps) pokazuju kako je tu riječ o nemaloj mjesnoj graditeljskoj baštini. Zatim su tu poslovi 
na obradi zemlje i skrbi o "blagu" (kako Podgorci vole zvati stoku) te različiti kućanski poslovi svrha kojih je obiteljska proizvodnja odjeće (najčešće od vune); alata; obuće: poznatih "šlapa"; kućanskih pomagala.

Zaoštrenije rečeno, u podgorskom životnom okviru teško je razlučiti životno vrijeme posve odvojeno od radnih napora (ne računa se vrijeme sna ili blagdansko vrijeme). Sve je - rad. U obvezujućim poslovima pretežu poslovi gdje je nužan veliki radni napor, pa ih i nije pogrešno držati svojevrstnom tlakom. Pri tomu se lik tlačitelja uglavnom ne ocrtava u obrisima socijalnog sudionika. Ocrtava se naprotiv, u obrisima prirodne zbiljenosti kakva vlada Velebitskom prirodnom padinom. Ekstremni ergonomijski tlak, dakle, oblikuje se početno kao označitelj poopćene životne kakvoće -mjesnog područja. On, posredno, pokazuje koliko je mjesno društvo "potonulo" u njegovu "prirodnost". Veljko Rogić, u spomenutu radu, govori o "škrtoj prirodnoj sredini". Ekstremni ergonomijski tlak, nužan za tamnošnji društveni život, zrcalni je otisak te škrtosti.

No, na drugoj strani, vidljiva je i mutacija toga označitelja u označitelja - socijalne razlike. Razlikom se razdvaja podgorsko područje s njegovom težačkom "prirodnošću" od - gradske zbilje, poglavito gradske zbilje u Senju. Senj ni po upisu razlike koja se stavlja u igru ovim označiteljom ne spada na ostalo područje Velebitske primorske padine. Pri tomu se, dakako, ne niječu sve one središnje silnice koje se iz grada Senja pružaju prema podgorskom području. Ne niječe se ni napornost dnevnog života u senjskoj svakodnevici. Ali je izvan sumnje kako sama gradska kakvoća života u Senju ne dopušta uspostaviti jednakost između ergonomijske zbilje podgorskog područja i mjesnog društva i zbilje grada Senja. Daljnja mutacija ovoga označitelja u javnoj imaginaciji vodi razdiobi kojom se dijeli težački svijet od "gospodskog" svijeta. Na tom je tragu, primjerice, skromni razvitak turizma na podgorskom području označen u mjesnom društvu kao mogućnost zarađivanja za - "kruva bez motike".

Moderne/postmoderne mijene gospodarstva od osamdesetih godina prošlog stoljeća dalje, svezane s izumiranjem "tradicionalnog" poljodjelstva na području, masovnom odselidbom s područja te općenitim snaženjem tercijarnog sektora gospodarstva, zacijelo brišu brojne poslove s ugrađenim ekstremnim radnim naporima. Pa i nije netočno ustvrditi kako Podgorci, neovisno jesu li ostali živjeti na području ili su odselili, više nisu - težačkom skupinom. Ali je očito kako se na samom području Velebitske primorske padine ne može računati s potpunim nestankom poslova koji nalažu velike napore. (Primjerice, održavanje mreža mjesnih putova, obnova zapuštenih naselja, održavanje 
okućnih parcela, održavanje pojedinih infrastrukturnih mreža itd.) "Hrvanje" s podvelebitskim prirodnim silama ostaje, dakle, i dalje gdje je i bilo. No sada se odlučnije upisuje u označitelje područja.

\section{Tehnička konzervativnost}

Prije skicirani uvidi skoro predvidljivo snaže analitički interes za tehničke sklopove i mreže na podgorskom području. Uzme li se u obzir podgorska, gotovo protestantska, privrženost radu i radišnosti, razložno bi bilo očekivati brojne poticaje na tehnička poboljšanja, i, općenito, tehničku modernizaciju. Pri tomu je korisno upozoriti, na tragu Arnolda Gehlena, kako je svodnja tehnike na ukupnost uporabljenih sredstava u radnom postupku "prekratka" doprijeti do njezine biti. Tehnika se, naprotiv, oblikuje (i samooblikuje) kao otvoreno polje čovjekovih "produžetaka", pa o njoj valja misliti kao o čovjekovoj "drugosti", s obilježjima bitno različitim od biotičke "prirodnosti" tijela (ne/ljudska, nad/ljudska, "drugost"). Tehnika, dakle, prekoračuje granice racionalna (proračunskog) djelovanja i "proizvodi" društvenu zbiljnost po predlošcima nesvodljivim na "prirodne" sektore života. U modernim/ postmodernim društvima ona na sebe preuzimlje i ulogu jednog od središnjih jamaca - moderne slobode (čitaj: sposobnosti za razvitak). Stoga se i rasprave o praksama "hrvanja" društva s prirodnim silama i prirodnom nadmoći ne mogu odvojiti od rasprave o tehničkoj konzervativnosti.

Množina činjenica navodi na predpostavku kako u razdoblju "starog Podgorja", (približno do sedamdesetih godina prošlog stoljeća) tehnička konzervativnost nadkriljuje malobrojne inovacijske pokušaje i poduhvate na području. Ona nije posebnom novošću. Na tehničku konzervativnost "morlačkog", dakle, seljačkog svijeta u dalmatinskom zaleđu podsjeća još Alberto Fortis (1774.) u: Putu po Dalmaciji. Premda je Fortisovo izvješće napisano osloncem na, ponovimo s Ninom Raspudićem, poluorijentalizam, Fortisova usputna zamjedba o "zapuštenosti" radnog oruđa u "morlačkim" kućanstvima nije bez uvjerljivosti. Tamo pretežu jednostavni tehnički sklopovi, iz kruga tehničkih pomagala koje Arnold Gehlen zove tehnikom nadomjestka, ili tehnikom pojačanja, iz kruga, dakle, jednostavnih tehničkih proteza. U oba ta kruga tehničkih pomagala središnja je tehnička stvarnost - ljudsko tijelo. Ono se prema izvanjskoj zbilji tehnički "usavršava" različitim pomagalima, ali se tek neznatno mijenja njegova uloga središnjeg energijskog pokretača tehničkog procesa. Tehničko tlačenje tijela, sukladno tomu, ne spada na popis zabrana/isključivanja, s pomoću kojih se uređuje društveni okvir priznatosti, 
i status, društvenih sudionika. Skupa s ljudskim tijelom, u istoj tehničkoj stvarnosti, su/postoje i tijela "radnih" životinja (magarac, konj, vol) pa naznačena neodređenost društvene granice s obzirom na dopuštenu tehničku (zlo)uporabu tijela omogućuje svakako simboličnu, ali i praktičnu, "osmozu" ljudskog i životinjskog položaja. Podsjetiti je, i u selima na podgorskom području zabilježeni su primjeri gdje ljudi i "blago", navlastito konji - žive pod istim krovom.

Nije nužno Fortisove "činjenične" opise čitati doslovno. Ali je svakako korisno uzeti u obzir upućivanje na tehničku zapuštenost. Nju, uostalom, potvrđuju brojni opisi i analize hrvatskog seljačkog svijeta i u razdoblju prve hrvatske polu/modernizacije, nastali bilo na narodnjačkim, bilo pravaškim, bilo radićevskim poticajima. Iz ponuđenih uvida razložno je zaključiti kako tehnička zapuštenost i nije navlastitim svojstvom "morlačkog" svijeta; ona bitno određuje položaj hrvatskog seljaka u promatranom razdoblju. Budući da je i pučanstvo Velebitske primorske padine, vidjelo se, uglavnom seljačko, nema dostatna razloga očekivati ovdje drugačiju tehničku zbiljnost. To znači da je u "starom Podgorju" tehnička konzervativnost učinkom i više nego oskudnih (ne)mogućnosti u pristupu tehničkim inovacijama. One su, vidjelo se, koliko podgorske toliko i hrvatske. No ta činjenica ovdje, za razliku od drugih hrvatskih krajeva, osnažuje označenost područja nadmoćnom prisutnošću prirodnih sila, dakle, odlučnije riva područje prema spominjanu simboličnu ispadanju iz povijesti.

Dopušteno je ovdje predpostaviti kako će pomorske prakse i subkulture u obalnim naseljima otvoriti vrata barem nekim poticajima. Podatci o razvitku brodarstva u devetnaestom i prvoj polovici dvadesetog stoljeća u, primjerice, Senju, Karlobagu, Jablancu (a i na području jugoistočno od Karlobaga), što ih je svojedobno prikupio Radojica F. Barbalić (1970.), nagovješćuju kako takva predpostavka i nije bez temelja. No nagodbenjački okviri unutar kojih se oblikuje prva hrvatska polu/modernizacija, a i "kontinentalni" prežitci života na Vojnoj granici (oko 1850., udio luka Vojne granice u ukupnu prometu na istočnoj jadranskoj obali obasiže tek $1,4 \%$ ) djeluju u oprečnu smjeru. Toj tehničkoj "zaleđenosti" sukladna je i infrastrukturna politika na području, točnije, manjak te politike. Ona se svodi pretežno na preventivne poduhvate, na primjerice, uređivanje "konala" u naseljima za obranu od bujučnih poplava ili na popravke pristaništa za redovitu linijsku plovidbu (od sredine devetnaestog stoljeća). Tromost bitno ne mijenja ni promet važnijim cestama: Jozefinskom od Senja prema unutrašnjosti ili cestom Karlobag - Gospić. 
Prilike se znatno mijenjaju u razdoblju druge (socijalističke) modernizacije, dakle, pretežno od sredine šezdesetih godina, (kada odpočinje i snažnija odselidba s područja). Područje se elektrificira što bitno mijenja tehničku "arheologiju" na području (na njemu se instalira i hidroelektrana Senj); modernizira se i uređuje jadranska cesta (dionica od Novog Vinodolskog do Zadra krajem pedesetih godina) te snaži uporaba osobnih vozila; osamdesetih se izgrađuje i vodovod Hrvatsko primorje - Južni ogranak iz Senja osloncom na kojega se poslije razvijaju i vodoopskrbne mreže pojedinih naselja. No, u istom razdoblju politički poredak drži seljaka nekom vrsti statističke građe, potrebne za ubrzano stvaranje radničke većine u društvu, koje do tada nema, a bez koje se poredak ne može valjano legitimirati. Stoga su spomenuti poduhvati zahvaćeni strukturnim zakašnjenjem. "Staro" podgorsko društvo je u odselidbi, kako je naznačeno, već našlo uspješniji način prevladavanja teškoća. Ostalo je područje, unatoč nemalim promjenama, podvrgnuto nadmoći prirodnih označitelja.

\section{Slaba socijalna gustoća mjesnog društva}

Na malobrojnost stanovništva na podgorskom području, kao i na malu gustoću nastanjenosti, ukazuje već i Veljko Rogić u spomenutu radu iz 1958. godine. $\mathrm{Na}$ istom su tragu i novije analize, primjerice, rad Dragice HusanovićPejnović (2010.). Iscrpnije izvijestiti o nalazima te analize nije ovdje nužno. Za svrhu rada dostatno je podsjetiti na nekoliko osnovnih podataka. Po popisu stanovništva iz godine 2001., na cijelom području živi 12.275 osoba. (Od toga, 5.491 osoba živi u Senju/naselju, u Karlobagu/mjestu 510, ili, zbrojeno, nešto više od $49 \%$ od ukupnog broja popisanih na području.). Usporedba podataka dobivenih prijašnjim popisima pokazuje da se broj stanovnika na području stalno i postojano - smanjuje, počevši od vršne, 1910. godine, kada je na području popisano 26.217 osoba. U usporedbi s brojem popisanih godine 1961., (kada je popisano 18.712 osoba na području) broj popisanih godine 2001., iznosi (u postotku) 66\%.

Posebno su znakoviti podatci o gustoći naseljenosti. Dragica Husanović - Pejnović analizom podataka za razdoblje 1961. - 2001., pokazuje kako se i ona smanjila: od 16,6 stanovnika po kvadratnom kilometru godine 1961., na 12,3 stanovnika po kvadratnom kilometru godine 2001. Sve područne gustoće (po gradovima i općinama) godine 2001. višestruko su manje od prosječne gustoće nastanjenosti u Republici Hrvatskoj (78,4 stanovnika po kvadratnom kilometru), osim u općini Jasenice gdje je ta gustoća manja "samo" približno 2 
i pol puta (31,3 stanovnik po kvadratnom kilometru). Ekstremno male gustoće nisu zabilježene samo u nekolikim primorskim naseljima (Senj, Karlobag, Sveti Juraj). Podatci dobiveni popisom 2011., bitno ne mijenjaju osnovne odnose pa ih ovdje i ne "prepisujemo".

Kao što je poznato, na sociologijsku važnost brojnosti i gustoće naseljenosti posebno upozoruje morfološki orijentirana analiza, korijeni koje su u radovima sociologijskog klasika Emila Durkheima. Gustoća naseljenosti drži se uvodnim pokazateljom u analizi socijalne gustoće. "Morfološki" promatrana potonja je od prve neodvojiva. Ali se ne može na nju svesti budući da socijalna gustoća cilja na brojnost međusobnih kontakata, odnosa, interakcija, što ih društveni sudionici međusobno uspostavljaju i oblikuju. Interakcijama se razvijaju različite odnošajne mreže unutar kojih se socijalna zbiljnost tek učvršćuje kao posebna zbiljnost. Iz modernizacijske perspektive socijalna se gustoća javlja kao polje brojnih međusobnih poticaja i prijenosa socijalnih energija, zamisli, znanja, habitusa, vrijednosti. Zahvaljujući socijalnoj gustoći društveni sudionici imaju pristup viškovima takvih tvorba. U javnoj komunikaciji one se "vodoravno" stvaraju, kruže i razmjenjuju. Na toj se podlozi lakše i uspješnije razvijaju i ustaljuju različite inovacijske prakse i "stilovi". A one su, poznato je, ključnim uporištima društvene modernizacije. Ako je gustoća naseljenosti mala i mogućnosti oblikovanja "gustih" odnošajnih i komunikacijskih mreža su slabe. To, pak, posredno znači kako društveni sudionici, budući da žive u zbilji "razrijeđenih" interakcija, ne mogu valjano sudjelovati u razmjeni različitih poticaja; a time slabe i njihovi izgledi u oblikovanju inovacijskih ponašanja. Drugačije rečeno, mala socijalna gustoća smanjuje i društvene mogućnosti unutrašnje, "odozdo", modernizacije društva.

Poslije su tom smjeru analize priključena još dva, "hibridna" pojma: ljudski i socijalni kapital. Ljudski kapital opisuje sposobnosti stanovništva za razvitak određenih djelatnosti (znanja, umijeća, habitusi, funkcionalne vrijednosti). Socijalni kapital opisuje pripravnost društvenih sudionika na međusobnu suradnju. Središnja je vrijednost u tomu - povjerenje. Na temelju povjerenja što ga društveni sudionici međusobno oblikuju i razvijaju snaže ili opadaju sposobnosti zajedničkog djelovanja, a time i mogućnosti optimiziranja raspoloživih socijalnih energija i inovacijskih praksa. Ne raspolažemo istraživačkim podatcima o socijalnom kapitalu u mjesnom podgorskom društvu. Tematski i teritorijalno najbliža su istraživanja Anite Bušljete Tonković (2014.) socijalnog kapitala na području središnje Like. Podgorskom području središnja je Lika "slična" po negativnim demografskim procesima kao što su depopulacija, odselidba, starenje stanovništva. Stoga je razložno predpostaviti kako je i na 
podgorskom području prisutniji "povezujući" tip socijalnog kapitala, osloncem na kojega se učvršćuju mreže osnovne solidarnosti (uzajamna pomoć, potpora u nevolji, rentijerski kolektivni zahtjevi adresirani na javne usluge, i slično). Fizička odvojenost malih naselja može, također, snažiti i sklonosti zataškavanju eventualnih slučajeva kršenja zakonskih ili moralnih norma u susjedstvu. Koliko su naznačene predpostavke činjenično utemeljene - ne znamo. No, već i uvidi nabačeni u prijašnjem ulomku o tehničkoj konzervativnosti na području, dopuštaju predpostaviti kako je "akumulacija" socijalnog kapitala "premošćujućeg" tipa, inače pogodnija za inovativno i razvojno ponašanje, slaba. Pojedini primjeri inovativna ponašanja u, primjerice, izgrađivanju kuća za najam turistima, organizaciji usluga za sezonsko turističko tržište, preradi mjesnih kulturnih tradicija u turističke spektakle, i srodni, na žalost bez sustavna opisa i valorizacije, pokazuju kako s takvim, premda skromnim, sposobnostima treba računati. Ali ih, na drugoj strani, nadkriljuju brojni primjeri "kokošarskog" ponašanja amalgamirani iznutra solidarnošću "unazad". U njima je lako nazrijeti pečat područja dugoročno potisnuta na simbolično klizište ispadanja iz povijesti.

\section{Promjena razvojnog subjekta}

Uvodno treba od promjene nagoviještene podnaslovom odvojiti dva niza promjena. U prvom nizu su brojne, male, promjene koje se događaju u podgorskim naseljima "po prirodi stvari". One su učincima kakve/takve otvorenosti naseljskih zajednica, navlastito naseljskih zajednica na obali. Njihovi učinci ugrađuju se u postojeće predloške društvene organizacije i ne dosežu do "dubljih" društvenih okosnica. U drugom nizu su promjene u gradskom društvu, ponajprije Senja, te, Karlobaga, Jablanca ili Obrovca. U odnosu na ostalo podgorsko područje te se promjene oblikuju u okvirima posebnih gradskih evolucija. Pojedini odsječci takvih evolucija mogu biti izravnije svezani s događajima na širem podgorskom području, ali i ne moraju. Stoga je manje pogrešno držati kako su na djelu koliko/ toliko autonomni procesi u usporedbi na ostalo podgorsko područje. Posebno kada se raspravlja o urbanoj evoluciji/ involuciji grada Senja.

Promjena razvojnog subjekta mjesnog društva, na koju se ovdje cilja izravno je svezana s, već stoljetnom odselidbom (uvjetno se godina 1910., kada je zabilježena i najbolja demografska bilanca na području, može držati simboličnim nultim datumom). Odselidbom su se oblikovale područno različite podgorske dijaspore: "šlavonska", vojvođanska, zagrebačka, riječka, zadarska, istarska, "amerikanska". Odselidbom su, dakako, mnogi odseljeni 
prekinuli svaku vezu sa zavičajnim, podgorskim, područjem. Ali su se u manjim skupinama odseljenih i njihovih potomaka ustalila i stabilnija sjećanja na zavičajno područje. Iz tih se skupina novače i potonji graditelji kuća za povremeno stanovanje, ("vikendica"), uglavnom u sutonskom razdoblju socijalističke modernizacije, te u razdoblju po završetku Domovinskog rata (1990. - 1998.). Oni se javljaju kao, do tada nepoznata, skupina: privremeni/ povremeni stanovnici područja.

Iz prijašnjeg se ulomka brzopleto može zaključiti kako članove te skupine na graditeljske poduhvate na zavičajnom području pokreće zavičajna nostalgija. Nije taj zaključak netočan. Ali nije ni potpun. U razdoblju od, približno, 1975., godine, kada odpočinje masovnija "betonizacija" hrvatske jadranske obale, na djelu je više usporednih poticaja na sekundarno građenje. Među njima svakako je i potreba za obnovom zavičajnih veza i obiteljskih povijesti. Ona, potreba, nekom je vrsti polemična uporišta odpora spram općenitih mitologema socijalističke modernizacije kojima je u srži birokracijska dobrobit $i$, ako se hoće, zatiranje obiteljskih i osobnih, (da se i ne veli nacionalnih), posebnosti u apstraktno jedinstvenoj masi i klasi. Drugi, nezanemarivi poticaj ima korijen u odporu ekonomiji socijalističkog razdoblja. Kao što je poznato, inflacijski postotci od sredine osamdesetih godina prošlog stoljeća mjere se troznamenkastim, a kadikad i četveroznamenkastim indeksima. Ulaganje u kuće za povremeno/privremeno stanovanje javlja se u ovom kontekstu kao - racionalna štednja, i investiranje posve prilagođeno obiteljskim i osobnim prilikama. Treći, također nezanemarivi, poticaj, ima korijen u "sivom" poduzetništvu gdje se računa s dobitima od iznajmljivanja kuća turistima. Budući da su i "krovni" razvojni dokumenti poretka nakon 1975., (prostorni planovi "južnog" i "gornjeg" Jadrana) jasno nagovijestili da poredak dugoročno računa $s$ turističkim tržištem kao važnim izvorom konvertibilna novca, investicijska ulaganja u kuće za iznajmljivanje turistima nakon 1975., više nemaju "ridikulozna" obilježja. Posrijedi je dugoročno racionalno i novčano isplativo ponašanje. Najzad, na ulaganja u "vikendice" potiče i kulturna potraga za drugom životnom pozornicom, s onu stranu industrijske monumentalnosti i nereda gradskih društava, dakle, neka vrst potrebe za privatnom režijom osobnih i obiteljskih idealnih/utopijskih stanja.

Ponuđena skica osnovnih poticaja implicira kako se u novu skupinu povremenih/privremenih stanovnika na obalnom hrvatskom području novače i graditelji bez sadržajnije veze s odabranim područjem građenja i povremena/ privremena stanovanja. Za razliku od skupine koja se pozivlje na zavičajno podrijetlo, makar nerijetko i posve simbolično određeno/neodređeno, u 
imaginariju "furešta", "doklaćenih", odabrana se mjesta građenja i povremena/ privremena boravka javljaju kao - izabrani zavičaji. U osnovi, odlukom, izborom, identificira se i zavičaj u brojnih obnovitelja starih kuća, podrijetlom sa zavičajnog područja, koji pripadaju drugom, trećem ili četvrtom naraštaju prije odseljenih a koji su teritorijalno socijalizirani na drugim mjestima. Analitički podatci pokazuju kako je u mnogim hrvatskim obalnim naseljima udio takvih, povremenih/privremenih, stanovnika nezamemariv. Budući da su oni prirodno zainteresirani za općenite poboljšice područja gdje su investirali u nekretnine, u mjesnom društvu javljaju se kao navlastiti subjekti mjesnog razvitka i utjecaja.

Nastaju, dakle, dvije nove utjecajne adrese. Prva je izvanjskom: dijaspora prisutna na različitim zaglavnim adresama. Ona može biti manje ili više umrežena, manje ili više "ujedinjena". Ali je izvan rasprave kako se u njezinim mrežama akumulira nezanemarivi ljudski i socijalni kapital. Ona se, dakle, ovisno o tipu mjesnog razvitka, može pojaviti kao moćni, izvanjski, razvojni sudionik i saveznik. Druga je adresa unutrašnja. Na toj su adresi svi novi povremeni/privremeni stanovnici mjesnog područja, neovisno jesu li podrijetlom s područja ili su "doklaćeni" po slobodnu odabiru. Oni nisu stalnim boravkom "sudbinski" svezani s područjem. Ali su barem interesno upućeni na sudioništvo u mjesnoj razvojnoj politici. Budući da je i u toj skupini nezanemarivi ljudski i socijalni kapital i oni se nameću kao razvojni sudionik i saveznik mjesnog društva. (A kadkad i kao izvor ugroze.)

Iz prije ponuđenih osvrta na neke ključne odnose i stanja na podgorskom području vidljivo je kako je, u osnovi, na djelu socijalni razvitak s posve predvidljivim rezultatom: ostvaruje se dugoročna nadmoć prirodnih sila i uvjeta, a slabe razvojne sposobnosti mjesnih društava (simbolično ispadanje iz povijesti). Taj je proces nešto sporiji na obalnom potezu, no u igri su, dugoročno promatrano, nijanse: na djelu je razvojna involucija. Središnji učinak tog procesa svodi se na socijalno i simbolično iskustvo trajno osporena života na podgorskom području (misli li se na njega pod vidom trajnog boravka na području). No, u isti mah, u obzoru takva iskustva nazire se povremeni/ privremeni boravak na području kao posve racionalni obrazac smanjivanja rizika i optimizacije odabranih životnih uvjeta. Usporede li se osnovni podatci o privlačnosti podgorskog područja povremenim/privremenim graditeljima s podatcima o privlačnosti drugih hrvatskih obalnih krajeva lako je uočiti kako je podgorsko područje "nekonkurentno". Graditeljski tlak na istarskom, riječkom, vinodolskom ili dalmatinskom odsječku hrvatske jadranske obale puno je snažniji. Ali nije posve odsutan ni na podgorskom području. To znači da 
se i u podgorskim naseljima postupno ustaljuje promjena koja mijenja glavne razvojne adrese na području. Koliko je vidljivo, povremenici/privremenici ne teže "heroičkom" hrvanju s prirodnim silama na velebitskoj primorskoj padini, što određuje, ponovimo sa Stjepanom Vukušićem, "staro Podgorje". Oni, naprotiv, polaze od toga da je prevlast prirodnih sila na području - nulto stanje. Svoje glavne interese, pak, oblikuju težnjom k, uglavnom povoljnim, potrošačkim položajima s obzirom na infrastrukturu i komunalne usluge. $\mathrm{S}$ takvih adresa svakako se novače i malobrojni novi stalni stanovnici, pa im se ne može odreći kakvoća neke vrsti demografske "utjehe". Ali na strategijskoj razini s tih se adresa ne premašuju ograničenja rentijerskog pristupa mjesnom razvitku. Koliko je on udaljen od ciljeva nacionalnog razvitka na području teško je reći jer bi najprije trebalo ustvrditi - postoje li, uopće, takvi ciljevi.

\section{K pitanju o uporištima revitalizacije Podgorja ili o kocki koja ne ukida slučaj}

I u uporabljenu međunaslovu, a i u samom naslovu ovoga teksta, rabi se riječ: revitalizacija a ne složenica: mjesni razvitak ili koja njoj srodna. Glavni razlog tomu leži u prije ponuđenu uvidu u "stanje stvari". Stavi li se u zagradu grad Senj (naselje), kako je prije i naznačeno, ostaje "na kirurgijskom stolu" mjesno područje na koje je teško, s obvezujućom metodologijskom čistoćom, primijeniti standardne pojmove razvojnih analiza i razvojnih scenarija. Stoga je manje netočno koristiti pojmovnik što se sabire oko pojma: revitalizacija. Uporaba toga pojma implicira kako je, u vremenskom pogledu prijašnji, model promjena ili, ako se hoće, razvitka, područje gdje se odigrava usmjerio prema slabljenju razvojnih sposobnosti mjesnih sudionika ako ne i njihovu potpunu iscrpljivanju. Pa je nužno pristup budućem mjesnom razvitku učiniti ovisnim o predhodećoj pripremi i oblikovanju nužnih uporišta toga razvitka. Iliti, drugačije rečeno, potrebno je odgovarajućim postupcima revitalizacije, "oživljavanja", područja mjesno društvo dovesti do stanja kada može, barem djelomično, prihvatiti odgovornost za navlastiti (budući) razvitak. Uporaba pojma "revitalizacija" implicira kako se revitalizacijski postupci ne mogu/ne smiju reducirati na izolirane, sektorske skupine promjena, kakve se, nerijetko, adresiraju u hrvatskom društvu na pojedine gospodarske grane. Revitalizacija je i po zahtjevima i po "tematskoj" širini promjena opsežnija i sadržajnija od takvih sektorskih praksa. Razlog je jednostavan: ona ima izgleda samo u uvjetima kritičke provjere predhodećih razvojnih strategija i snaženja njihovih strukturnih preinaka. Sukladno tomu, nameće se potreba za svojevrstnim 
prijekidom brojnih postojećih silnica i u institucijskoj mreži i u svakodnevici mjesnog društva.

(a) Promjena javne predodžbe o subjektu mjesnog razvitka. Iz prijašnjih ulomaka je očito kako su se razvojne mogućnosti mjesnog društva - iscrpile. Malobrojnost pučanstva, mala gustoća nastanjenosti, mala socijalna gustoća i s njom svezane teškoće u oblikovanju većeg socijalnog kapitala, veliki postotni udio pučanstva starijeg od 60 godina (više od $30 \%$ ), na vrhu su popisa negativnih čimbenika. $\mathrm{K}$ tomu, naselja s malim brojem stalnih stanovnika teško mogu u procesima odlučivanja lokalne samouprave nametnuti uklanjanje teškoća u vlastitu naselju kao poopćene razvojne ciljeve: to bolje uspijeva naseljima $\mathrm{s}$ brojnijim stalnim stanovništvom.

Iz prijašnjih je ulomaka vidljivo, međutim, kako su dvije teritorijalne skupine prvi kandidati za proširenu "definiciju" mjesnog razvojnog subjekta. Prva su skupina, vidjelo se, povremeni stanovnici. Premda, najčešće, njihovo djelovanje na mjesnom području ostaje u granicama rentijerskih pritisaka na infrastrukturne i uslužne mreže, nije bez činjenične potpore ocjena kako se iz te skupine novače i članovi dublje privrženi dobrobitku mjesnog društva i skloniji uložiti i ljudski i socijalni kapital u mjesne poboljšice. Druga su skupina, vidjelo se, odseljeni s područja. Brojni podatci pokazuju kako i Hrvatska, kao nacionalna država, ima teškoća $s$ oblikovanjem uspješne razvojne politike spram hrvatske inozemne dijaspore. Razložno je očekivati kako se te teškoće "prelijevaju" i na mnoge jedinice lokalne samouprave. No, nije posve nepoznato kako se takve teškoće nadmašuju i kako se valjano oblikuju dugoročne politike suradnje i - povratka. Spomenute dvije, "izvanjske" skupine, u savezu s malobrojnim mjesnim pučanstvom, mogu znatno "iznutra" obnoviti razvojne energije na području. No za takav savez potrebno je kritički ocijeniti aktualni institucijski okvir u kojemu se legitimiraju razvojni sudionici mjesnog društva.

b) Nova kulturna strategija u odnosu na područje. Ta strategija ima dvije osnovne razine. Na prvoj razini očituje se "negativno": kao praksa dekonstrukcije, prije spomenute "kocke koja ukida slučaj". Ili, drugačije rečeno, očituje se kao trajna kritika "tijesna" načina označivanja Primorske velebitske padine područjem $\mathrm{s}$ ruba povijesti/kulture ili, pače, ispalim iz povijesti. Time se ne pozivlje na odpor težnjama što ističu brojne prirodne/ ekologijske vrijednosti područja. Značenjski omot u kojemu se glavni označitelji izvode iz prirodnih sila $i$, općenite, "prirodnosti" područja u suvremenim razvojnim praksama, izrazitije prožetim ekologijskom skrbi za kakvoću prirodnog okoliša i zdravlja stanovništva, ne izgleda, uostalom, odveć "tijesno". Pače, takav značenjski omot olakšava odvažnije zaštitne pristupe 
prirodnoj zbilji. Posredno, na to ukazuju i dvije ustanove za zaštitu prirode na području (park prirode Velebit i nacionalni park Sjeverni Velebit). Drugačije rečeno, s podporom takva značenjskog omota područja lakše se i dosljednije uspostavljaju potrebne politike zaštite prirode na području.

No isti je značenjski omot odveć "tijesan" za valjanu sociokulturnu integraciju područja u cjelinu nacionalnog teritorija. Razlog je, u osnovi, jednostavan. Za takvu integraciju potrebno je u značenjski omot područja ugraditi simbolične sklopove koji čvršće povezuju obilježja područja sa socijalnim i kulturnim simbolima. Ilustrativni primjeri takve vrsti najjasniji su u hrvatskom pjesništvu, navlastito u tekstovima tematski podređenim Velebitu. Premda se u množinu takvih tekstova upisuje tek divljenje spram mjesnog krajolika mogu se pronaći i razvijenije simbolične veze Velebita s, primjerice, svetom planinom (uostalom jedan se velebitski vrh i zove svetim), obrambenom tvrđom, neuništivim tijelom (zajednice) i srodnima. Njihova "funkcionalnost" bolje se razumije definira li se negativno: one priječe simboličnu banalizaciju područja. Koliko je vidljivo, ni dosljedna ekologijska zaštita "prirodnosti" područja nije dugoročno održiva ako na području nije uspostavljen kakav-takav poredak sociokulturnih simbola. I takva zaštita, naime, bez njih lako kliže u "prirodnjačku" banalizaciju. Pozivlje se, dakle, na oblikovanje drugačijeg simboličnog polja gdje se priroda ne pojavljuje kao kolonizacijska sila nad mjesnim društvom, nego kao njegova posebna sociokulturna vrijednost $i$ prednost.

Na drugoj razini nova bi se kulturna strategija imala očitovati "pozitivno". U takvu simboličnu zrcalu bunjevačkih 300 godina na području ne može se rastvoriti u reduciranoj povijesti sirotinje i periferijske zapuštenosti, premda, dakako, i takvi procesi spadaju na bilancu ta tri stoljeća. Može se, naprotiv, pokazati kako je u temelju te mjesne "zgode", a na tragu sugestija Stjepana Vukušića, zajednica koju iznutra amalgamira - identitet odpora brojnim nadmoćnim čimbenicima pretežno prirodnog, ali i društvenog podrijetla. Ili, drugačije rečeno, moguće je oblikovati "alternativni" simbolični obzor unutar kojega se područje označuje označiteljima bližim "herojskim", "junačkim", modernije: uspješnijim, osnovama. Koliko je vidljivo, taj se pristup u sadašnjosti rabi reducirano, (obnovom sjećanja na senjske uskoke). $\mathrm{Na}$ tragu identiteta odpora moguće je pokazati da je bunjevačkih 300 godina na području primjer - svojevrstnog razvojnog uspjeha. Koristeći model raspršene nastanjenosti i male gustoće, bunjevačka je zajednica uspjela nemalih 300 godina biti ekskluzivnim gospodarom područja gdje se sabrao uvjerljivo veći broj rizika prirodnog i političkog podrijetla nego na drugim područjima. No na 
taj posao moraju se pozvati - intelektualci. A njih, poznato je, razvojne politike u Hrvatskoj pretežno drže dijelom problema, a ne dijelom rješenja.

(c) Definicija nove funkcionalne vrijednosti područja na nacionalnoj razini. Kao što je poznato to je, ponajprije, koncepcijska zadaća tvoraca nacionalne prostorne strategije i pristupa nacionalnom razvitku. Nakon koliko toliko jasne nacionalne strategije povratka hrvatskog pučanstva (1995. - 2000.) na "zavičajna područja", pučanstva prognana tijekom drugojugoslavenske i srpske/crnogorske agresije, nije vidljiva jasnija ili odlučnija politička volja koja bi bila čvršće svezana s određenim vidovima nacionalne prostorne politike. $\mathrm{Na}$ djelu su, poznato je, pretežno "spontani" procesi, kao neka vrst "prirodnih" produžetaka ili procesa iz socijalističkog razdoblja (propadanje sela, bijeg stanovništva s pograničnih područja, privlačnost velikih gradova) ili procesi osnaženi promjenama u novom političkom i gospodarskom modelu (gubitak radne sigurnosti, kraj razdoblja masovna zapošljavanja, snaženje turističkog tržišta na hrvatskoj jadranskoj obali, politika otvorenih granica, i srodni). Obje vrsti procesa pokazale su se nedoraslima za ostvariti središnji nacionalni cilj na teritoriju: stalnu nastanjenost teritorija. U stručnom žargonu prostornih planera isti se cilj zove: "ravnomjerni raspored stanovništva". Negativno formuliran taj cilj može se definirati i ovako: ni u jednoj razvojnoj politici nacionalne države nije dopušteno (nije razvojno legitimno) "stvarati" područja bez stalno nastanjena pučanstva. (Zaštićena područja ili rizična područja ne računaju se.) Na području Velebitske primorske padine, oštrije nego drugdje, događa se baš to: kako bi pjesnici rekli: pustinja raste. Stalna nastanjenost područja javlja se, dakle, na Velebitskoj primorskoj padini kao "nulti" imperativ, cilj što predhodi posebnim ciljevima. On mjesnu razvojnu politiku izravno suočava sa "slijepim mrljama" nacionalne prostorne i razvojne politike. Ali, ujedno, mjesnoj politici razvoja doznačuje i moćno sredstvo utjecaja na nacionalnu politiku. Kako se pri tomu dijele uloge gradova i općina, a kako županija, predmetom je posebne analize. No bez ostvarivanja toga cilja one ostaju praznim političkim formama.

Ostvarivanje spomenuta cilja: ponovnog naseljavanja područja, ne implicira obvezu stvaranja nove brojne populacije s velikim gustoćama nastanjenosti i gustim socijalnim mrežama. Bunjevačko tristogodišnje iskustvo, (a i predhodeće, starovlaško i starohrvatsko), pokazuje kako su na području, kako je naznačeno, raspršenost i male gustoće nastanjenosti odporniji od drugih načina gospodarenja teritorijem. Vjerojatno je da će oni odrediti održavanje stalne nastanjenosti i u budućnosti (pod uvjetima primjene aktivne demografske politike ako takve bude). Ali je moguće, navlastito na obalnom, primorskom, potezu istražiti modele naseljenosti djelomično 
drugačije od postojećih. Glavni razlog tomu je nestašica prostora u primorskim naseljima gdje se može graditi s malim ili umjerenim troškovima. (Primjerice, Senj, Sveti Juraj, Jablanac, Karlobag, pače, i Obrovac). Kako su se gradovi "otresali" od te teškoće vidljivo je u više primjera urbane evolucije zasnovane na "srastanju" naseljskih cjelina izgrađenih na različitim (nadmorskim) visinama. U neposrednom susjedstvu riječki je primjer najzorniji. Na djelu je stoljetni proces kojim se oblikovala moderna Rijeka u rasponu od "obalnog" Starog Grada do "kontinentalne" Rujevice. Na tragu srodna predloška moguće je razviti i, primjerice, istraživanja (budućeg) Senja na zaravni Vratnika; (budućeg) Svetog Jurja na zaravni od Crnike do Selina; Jablanca na zaravni uz Jadransku magistralu itd. Takav smjer analize podupiru i poopćene strategijske intencije u gospodarenju obalom: teži se izgrađivanje naselja, navlastito povremenih/privremenih, potisnuti s obalne crte na područja smještena dublje u kopnu, gdje je i lakše graditi, s manjim troškovima u graditeljskom "hrvanju" sa strmim terenima. Pak, dalje na Velebitskoj primorskoj padini ozbiljnu valorizaciju tek čekaju nekoliki "podovi" (na koje u svojim radovima nadahnuto upućuje Helena Knifić Schaps).

(d) (Re)valorizacija prometne cjelovitosti područja. Aktualni pristupi valorizaciji prometne cjelovitosti područja temelje se, uglavnom, na isticanju vrijednosti uzdužne Jadranske magistrale te poprječnica: Senj - Žuta Lokva (Karlovac); ceste Stinica - Jablanac - Veliki Alan - Štirovača; ceste Karlobag - Baške Oštarije (Gospić); te ceste Sveti Juraj - Krasno (Kuterevo - Švica). Tomu se dodaju i kraći osvrti na, također popriječne, planinarske putove i staze, no srodniji ulomcima iz zamišljene rubrike: Da se ne zaboravi, nego li čemu drugom. Kritičniji uvidi u povijest područja pokazuju da na taj način ostaju izvan analitičkog "radara" tri prometne mreže s pomoću kojih se područje u prošlosti, također, teritorijalno integriralo. Prva takva, i svakako, najvažnija je pomorska prometna mreža. Od sredine devetnaestog stoljeća redovita linijska plovidba uspješno je integrirala obalno podgorsko područje i olakšavala tamnošnje strukturiranje mjesnih središta. K tomu, snažila je i težnje $\mathrm{k}$ čvršćem povezivanju otočnih društava na susjednim otocima (navlastito Paga i Raba) s mjesnim društvima na Velebitskoj primorskoj padini. Pokazalo se da "kontinentalizacija" te mreže, pretvaranjem Jadranske magistrale u glavnu prometnu "cijev" područja, šezdesetih godina prošlog stoljeća, nije bila optimalna sa stajališta mjesnih potreba i intencija. Druga takva, premda "sekundarna", je mreža poprječnih, ne samo planinarskih nego i konjskih, putova more - planina. Ona je u međuvrijeme, uglavnom, podlegla propadanju i ustrajnom širenju šikare i šume. Treća takva čak više 
ni "sekundarna", a dvojbeno je koliko se može označiti i riječju: mreža, je "mreža" putova s pomoću kojih su se međusobno povezivala naselja ili samo stanovi na različitim podovima, smještenim uglavnom na većim nadmorskim visinama. Dijelovi te "mreže" uključeni su u mreže planinarskih putova na području, ali je nemali dio prepušten društvenu zaboravu.

Koliko je vidljivo iz raspoložive razvojne dokumentacije jedinice lokalne samouprave na području, navlastito Grad Senj i općina Karlobag, ističu potrebu za obnovom pomorskog prometa. Izvoditi tu potrebu iz brojnosti stalno nastanjena stanovništva nije uvjerljivo. Ali izvoditi je iz razvojnih zamisli o budućem razvitku turizma i usluga, u okviru kojega se oblikuju različiti načini suradnje između susjednih otoka i podgorskog područja, nije bez temelja. Tomu se, premda pretežno s ilustrativnom vrijednošću, mogu pridružiti i podatci o brojnosti povremenih/privremenih stanovnika na području koji prihvatljivim drže način života izravnije prožet vezom s morem.

(Re)valorizacija ostalih dviju mreža nema korijen u jasno istaknutim razvojnim intencijama ili potrebama. Ali je potrebna kao neka vrst komplementarna odpora snažnim silnicama zaborava, ako ne i banalizacije sjećanja na - pristupačnost područja. $\mathrm{K}$ tomu, tako dobiveno javno znanje može biti i više nego korisno u različitim, posebnim, "projektima" revitalizacije bilo (raspršene), a stalne, nastanjenosti na "dubljem", kontinentalnom dijelu Velebitske primorske padine, bilo posebnih oblika mjesnog poljodjelstva $\mathrm{s}$ obvezujućom ekologijskom legitimacijom, bilo posebnih vidova planinarskog ili pustolovnog turizma. Posebni dobitak od takve (re)valorizacije očituje se u obnovi društvenog sjećanja na različita stara naselja, "počivala", "mirila" i na druge označitelje posebnih, baštinskih i svetih, mjesta kroz koje se nazire dublja identifikacija zajednica "starog Podgorja", sa zavičajnim područjem. Brojna posebna istraživanja graditeljskog i kulturnog naslijeđa na području u jednom se uglavnom ponavljanju: ističu zapuštenost i ugroženost te baštine na području. S kojim se izgledima i načinima ona uspješno može štititi predmetom je posebne rasprave. Ali je izvan dvojbe kako se (re)valorizacijom prometne cjelovitosti područja naznačuje barem osnovni okvir u kojemu se definiraju različiti vidovi pristupačnosti na području, a time i društveni/prostorni kontekst u koji je baština ukorijenjena.

(e) Gospodarska struktura relativno neovisna o prirodnoj osnovi područja. U više analiza gospodarske povijesti na području pokazalo se kako oslonac društva na gospodarske grane ovisne o mjesnim izvorima: na poljodjelstvo i stočarstvo, ne uspijeva mjesno društvo odvojiti od siromaštva. Ista tvrdnja pogađa i ribarstvo. Njihov razvojni potencijal ograničen je na 
potencijal pomoćnih gospodarskih grana, svezanih s poslovima na okućnici ili s ostvarivanjem posebnih ekologijskih, vrijednosti i ciljeva ("zdrava", ekologijski označena prehrana, stočarenje kao metoda obnove pojedinih biljnih vrsta, i slično). Drugačije rečeno: oslonac mjesnog društva na poljoprivredni sektor kao središnji sektor gospodarstva nema u budućnosti velikih izgleda. Posredno na to upućuju i masovne odselidbe s područja.

Koliko je vidljivo, tri posebna sektora gospodarstva mogu u budućnosti pronaći stanovita uporišta u prirodnoj "ponudi" područja. Na tom se popisu često spominje šumarstvo. No njegov razvitak, strogo govoreći, izmiče teritorijalnom okviru Velebitske primorske padine, a glavna uporišta nalazi u industrijskim središtima Gacke i Like. U svakom slučaju razvitak šumarstva proteže se i na podgorsko područje, ali je ono u tom razvitku - dodanim prostorom Razvitak turizma i turističkih usluga, međutim, izravno se naslanja na posebnosti područja (more, klima, prirodne vrijednosti, raspršena nastanjenost). U kojim će se posebnim oblicima mjesni turizam razvijati u budućnosti predmetom je posebnih kritičkih analiza. Ali je očito kako će posebnosti morati izvoditi iz odnosa spram prirodne zbilje i specifične nastanjenosti. Treći sektor koji je, djelomično, upućen na vezu s prirodnim vrijednostima područja je proizvodnja energije. Na području su vidljive mogućnosti razvitka energijske proizvodnje na tri načina: vjetroelektranama, elektranama sa sunčevom energijom te uporabom biomase (nastale $u$ šumarskoj industriji). Proizvodnja energije, međutim, upućuje i na dugoročnu važnost stvaranja gospodarskog sklopa koji je tehnički autonoman s obzirom na prirodna ograničenja područja. Drugačije rečeno, gospodarska optimizacija područja u budućnosti ostvariva je koncentracijom gospodarskih grana zasnovanih na "visokim tehnologijama". Lokacijski promatrano, one se mogu izgraditi na različitim područjima, pod uvjetom da su ta područja "standardno" uporabljiva. Budući da takvih mjesta ima i na Velebitskoj primorskoj padini nisu vidljivi načelni razlozi koji bi tomu stajali nasuprot. Buduća gospodarska struktura na području ostvariva je, dakle, uzme li se u obzir tehnička neovisnost o prirodnoj osnovi područja. Time se ne zagovara ekologijska indiferencija. Zaštićena "prirodnost" područja, vidjelo se, izravno se ugrađuje u njegove razvojne prednosti, pa i nema posebne potrebe $u$ to sumnjati. Toliko više, koliko su i gospodarske grane zasnovane na "visokim tehnologijama" razvijaju uključujući i brojna mjerila ekologijske obzirnosti. U tom odnosu manje su vjerojatni sukobi izvedeni iz strukturne nesukladnosti. Vjerojatnije su, naprotiv, kritičke provjere razvojne racionalnosti pojedinih praktičnih rješenja. (Primjerice, sadašnji režimi zaštite u parku prirode otežavaju na području razvitak proizvodnje energije u vjetroelektranama). No 
razvojni horizont u okviru kojega se takve nesukladnosti vrijednuju isključuje razvojne odluke zasnovane na modelu razvitka "uništavanjem osnove toga razvitka". To, drugačije rečeno, znači da je uspješna gospodarska struktura na području dugoročno ostvariva i "održiva" toliko koliko je tehnički inovativna, a ekologijski obzirna. Drugačiji pristupi, pokazalo se, okončavaju u odselidbama stanovništva i gubitku razvojnih sposobnosti. U osnovi, područje više i nema mogućnosti odabira: ili će pokušati s kakvom - takvom (post)modernošću ili ga, kao posebne zajednice - ne će biti.

(f) Izgradnja institucijskog sklopa. Uporišta revitalizacije, skicirana u prijašnjim ulomcima, ne mogu se osnažiti u okvirima postojećeg institucijskog sklopa u mjesnom društvu. Razlog je jednostavan: taj sklop nije razvojno centriran. Njegove su osnovne zadaće administrativna i proračunska "homogenizacija" područja. Iz razvojne perspektive, takav sklop pogodan je pretežno za statična društvena stanja, ili, pak, stanja koja se sporo mijenjaju - unazad. Snaženje spomenutih revitalizacijskih uporišta, međutim, traži razvojnu institucijsku infrastrukturu, sposobnu za aktivno uklanjanje glavnih zapreka smjerovima promjena što ih revitalizacija obuhvaća i "proizvodi". Pri tomu, nije nužno cijelu (novu) institucijsku mrežu zamišljati u isključivim okvirima mjesnog društva i njegovim glavnim središtima, navlastito u Senju. Više suradničkih institucija može se već sada identificirati u sklopu okolnih sveučilišta u Zagrebu, Zadru i Rijeci. Bitno je, ipak, da je stožerna institucija, koja praktično pokreće množi i koordinira potrebne inicijative, smještena u mjesnom društvu, (dakle, u Senju). Koliko je vidljivo iz dosadašnje prakse mjesna razvojna agencija u Senju mogla bi preuzeti, barem inicijalno, takve zadaće. U srži je takvih zadaća valjano povezivanje istraživačkih radova i programa s financijskim adresama na jednoj strani te s odabranim nositeljima pojedinih sektorskih promjena na drugoj. Korisno je, pri tomu, podsjetiti kako, u promijenjenu obzoru razumijevanja novog razvojnog subjekta mjesnog razvitka, područje djelovanja spomenute agencije, (a i njoj srodnih ustanova koje bi u budućnosti, eventualno, nastale) nadmašuje teritorijalne okvire mjesnog društva na Velebitskoj primorskoj padini. Rabeći različite integracijske mreže stvarne silnice takva djelovanja idealnotipično rečeno, trebale bi dosegnuti sve izvanjske skupine odseljenih i povremenih/ privremenih stanovnika na području. Koristeći njihov socijalni i intelektualni, (a i financijski) kapital, zacijelo bi se mogla, figurativno rečeno, baciti i kocka koja ovdje - "ne ukida slučaj". 
Izvori

Izvješće o stanju u prostoru od 2010-2014, Grad Senj, Zavod za prostorno uređenje i zaštitu okoliša Ličko-senjske županije, Gospić, 2015.

Izvješće o stanju u prostoru od 2010-2014, općina Karlobag, Zavod za prostorno uređenje i zaštitu okoliša Ličko-senjske županije, Gospić, 2015.

\section{Literatura}

Višeslav ARALICA, Gospodarstvo primorskih Bunjevaca, Senjski zbornik, 27, Senj, 2000, 227-234.

Mate (Majo) AŽIĆ, Podgorje, Da se ne zaboravi, rukopis, Rijeka.

Šime BALEN, Velebit se nadvio nad morem, Zagreb, 1985.

Radojica F. BARBALIĆ, Brodarstvo u Senju i Podgorju kroz prošlost, Senjski zbornik, IV, Senj, 1970, 5-32.

Anita BUŠLJETA TONKOVIĆ, Održivi razvoj Središnje Like, Prinosi analizi ljudskog i socijalnog kapitala, Zagreb/Gospić, 2015.

Milana ČERNELIĆ, Bunjevačke studije, Zagreb, 2006, 5-32.

Milana ČERNELIĆ, Osvrt na desetljetno sustavno etnološko istraživanje primorskoličkih Bunjevaca, Senjski zbornik, 40, Senj, 2013, 685-696.

Lara ČERNICKI - Stašo FORENBAHER, Starim cestama preko Velebita, Zagreb, 2016.

Aleksandra FABER, Život velebitskog stočara i njegov odnos prema smrti (Razmatranja uz mirila), Senjski zbornik, 22, Senj, 1995, 157-170.

Arnold GEHLEN, Duša u tehničkom dobu, Zagreb, 2004.

Dragica HUSANOVIĆ-PEJNOVIĆ, Demografski razvoj Podvelebitskog primorja u uvjetima periferije, Senjski zbornik, 37, Senj, 2010, 119-142.

Helena KNIFIĆ SCHAPS, Gradnja unutar parka prirode "Velebit" i nacionalnog parka "Sjeverni Velebit", Senjski zbornik, 29, Senj, 2002, 293-326.

Helena KNIFIĆ SCHAPS, Velebit arhitektonski, Pučka gradnja u dijelovima sjevernog i srednjeg Velebita, Zagreb, 2013

Ana LEMIĆ, Sela i stanovi na Velebitu. Svjedočanstva života od nastanka do nestanka, Gospić, 2013.

Ana LEMIĆ, Stjepan SUČIĆ (ur.), Velebit u hrvatskom pjesništvu, Gospić, 2014.

Blaženka LJUBOVIĆ(ur.), Lukovo kroz povijest, Senj, 2002.

Geran Marko MILETIĆ, U potrazi za drugim prostorom, Sociologijski aspekti sekundarnog stanovanja u Hrvatskoj, Zagreb, 2011.

Bojan MUCKO, Podaj majko - semiotička analiza podgorskog identiteta, Senjski zbornik, 36, Senj, 2009, 275-300. 
Stjepan PAVIČIĆ, Raseljenje starosjedilaca i doseljenje Bunjevaca u Senjski kraj, Senjski zbornik, II, Senj, 1966, 310-382.

Mirko RAGUŽ, Iz povijesti školstva senjskog kraja, Senjski zbornik, 17, Senj, 1990, 291-298.

Mirko RAGUŽ, Pučke škole u senjskom Podgorju, Senjski zbornik, 22, Senj, 1995, 369378.

Nino RASPUDIĆ, Jadranski (polu)orijentalizam, Prikazi Hrvata u talijanskoj književnosti, Zagreb, 2010.

Pavle ROGIĆ, Antroponimija i porijeklo stanovništva u naseljima srednjeg velebitskog Podgorja, Hrvatski dijalektološki zbornik, 2, Zagreb, 1966, 303-323.

Pavle ROGIĆ, Antroponimija u naseljima sjevernog Velebita, Hrvatski dijalektološki zbornik, 2, Zagreb, 1966, 324-355.

Veljko ROGIĆ, Velebitska primorska padina, Zagreb, 1958.

Ivan ROGIĆ, Anka MIŠETIĆ, Ratimir ZIMMERMAN, Kuća pokraj mora, Zagreb, 2006.

Drago ROKSANDIĆ, Bune u Senju i Primorskoj krajini 1719-1722, Radovi Zavoda za hrvatsku povijest Filozofskog fakulteta u Zagrebu, 15, Zagreb, 1982, 33-106.

Maja ŠTAMBUK - Ivan ROGIĆ - Anka MIŠETIĆ, Prostor iza: Kako modernizacija mijenja hrvatsko selo, Zagreb, 2002.

Maja ŠTAMBUK, Lica nigdine. Društveni i prostorni okvir razvitka hrvatskog sela, Zagreb, 2014.

Mirjana TROŠELJ, Mitske predaje i legende južnovelebitskog Podgorja, Studia mythologica slavica, XIV, Zagreb, 2011, 345-370.

Mirko VALENTIĆ, Velebitska mirila u istraživanjima Ante Glavičića i drugih te nekoliko hipoteza o narodu kojemu pripadaju mirila zajedno s njihovim dvovjerjem, Senjski zbornik, 40, Senj, 2013, 583-610.

Stjepan VUKUŠIĆ, Novakova i Barčeva slika Podgorja, Senjski zbornik, 15, Senj, 1988, 185-188.

Marin ZANINOVIĆ, Stanovništvo velebitskog podgorja u antici, Senjski zbornik, 10-11, 29-40, Senj, 1984, 29-40. 


\section{SIX GENERAL IDENTIFIERS OF THE VELEBIT LITTORAL HILLSIDE AND THE QUESTION OF REVITALISATION}

\section{Summary}

The paper is divided into two basic parts. In the first part the six basic identifiers are analysed with the help of which the existing meaningful framework is formed of the identification of Velebit littoral hillside in the public consciousness and imagination of contemporary Croatian society. They are: the supremacy of natural forces; deep poverty; extreme ergonomic (working) pressure; the technical conservatism of the local society; poor social density; the diffusion of the developmental subject of the region. When these features are observed mutually bound a semiotic 'portrait' of a region is obtained not only without a valid developmental future but also of a region functionally incapable of development. Therefore in the second part of the paper the question about the mainstays of the revitalisation of the region is actualised. The term used is: revitalisation, because with it, it wishes to point out, with the corresponding practices of revitalisation, how necessary it is to prepare the local society for active/autonomous development. In this search six basic (possible) mainstays of revitalisation are analysed. They are: a change in the public's notion of the subject of local development; a new cultural strategy in relation to the area; a definition of the new functional value of the area on a national level; the (re)valorisation of the transport integrity of the area; the formation of an economic structure relatively independent from the natural base of the area; the construction of a network of developmental institutions. Each mentioned mainstay rests on kinds of bundles of special practices which differentiate it substantively. However, it is important, therein, to recall how with an outlined approach of revitalisation the interpersonal connectivity of socio/ cultural changes is suggested, changes in the economic policy and the policy of the infrastructure, and in the constructing of the specific network of the developmental institutions. Or, to put it a different way, it concerns an area where with a classic 'sectoral' approach to local development the expected results will not be achieved.

Keywords: Velebit littoral hillside, revitalisation 